\title{
An Assesment of Export Potential of Indian Mentha Oil in International Market
}

\author{
Ashutosh Chaturvedi ${ }^{1 *}$, Sanjay Kumar ${ }^{1}$ and Rakesh Rathore ${ }^{2}$
}

${ }^{1}$ Department of Agricultural Economics, Sam Higginbottom University of Agriculture, Tecnnology and Sciences, Prayagraj, Uttar Pradesh, India

${ }^{2}$ School of Business Studies, Punjab Agricultural University, Ludhiana, Punjab, India

"Corresponding author: aashutosh1908@gmail.com (ORCID ID: 0000-0002-6331-0888)

Received: 22-05-2021

Revised: 25-08-2021

Accepted: 05-09-2021

\begin{abstract}
Mentha (Mentha arvensis) is an important crop cultivated in India. Uttar Pradesh is the leading producer state in the country. The present study has been carried out in order to access the export potential of Indian Mentha oil. The export potential and performance of Mentha oil was examined. Apart from this total export, export growth rate and stability or instability of trade for India was also examined. Growth rate analysis and Markov chain analysis were the analytical tools used to assess growth and transition probabilities matrix for the major Mentha oil markets. Data were collected from various published sources from the year 2010-11 to 2019-2020 to calculate the compound growth rate and export potential of Mentha oil. The result of the study revealed that U.S.A. is the most stable importer of Indian Mentha oil because it retain 79 per cent share in last ten years among all the countries. France reported as second most stable importer of India's Mentha oil had 0.49 transition probability. Japan, Brazil, Netherland, Spain reported zero transition probability, indicating instability in India's exports to these countries.

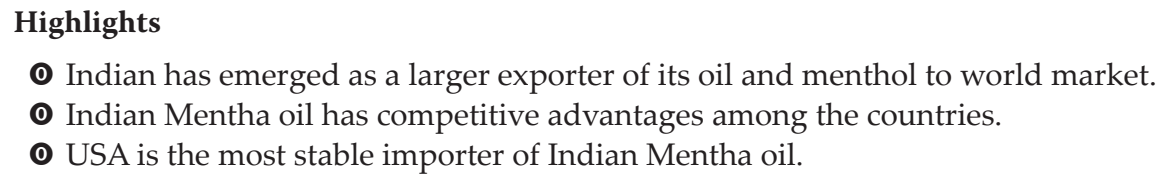

Keywords: Export potential, Growth rate, Mentha oil, Markov chain

India is a mainly agrarian economy since time ancient. The progress efforts over the last few decades have doubtlessly strengthened our industrial base. However, agriculture continues to be the backbone of our economy and even most of population depends on agriculture as livelihood and source of income. Mentha crop covers an area of approximately 2 lakh hectares in India, 90 per cent of which falls in Uttar Pradesh state alone with the remaining 10 per cent coming from smaller areas in the Punjab, Rajasthan etc. Barabanki district is the leading producer in Uttar Pradesh. Where menthol mint covers nearly 60,000 hectares of area. Barabanki district lies in the terai region that is suitable for mentha cultivation (Srivastava, Hindustan Times,
2013). Area has grown immensely during the last 3 years in Tarai district of Uttar Pradesh State and parts of Punjab and Haryana State. Benefit-cost ratio of Mentha cultivation returned more, which was prominently higher than that of other alternative crops and crop combinations. Mentha production is more financially feasible and profitable for farmers, both in case sole and intensive cultivation (Singh et al. 2019).

Indian has emerged as a larger exporter of its oil

How to cite this article: Chaturvedi, A., Kumar, S. and Rathore, R. (2021). An Assesment of Export Potential of Indian Mentha Oil in International Market. Economic Affairs, 66(3): 447-450.

Source of Support: None; Conflict of Interest: None (c) 9 
and menthol to world market, particularly to the USA. (CCARI). India is the world's largest producer and exporter of Mentha oil which is widely used as flavoring agent in food products including confectionery (Chandrasekhar, 2017)

At global level India dominates production with around 80 per cent to global supply, followed by China and Japan, each producing around 10 per cent. India exports around 25 to 30,000 tons in a range of forms (menthol crystals and powder, dementholised mint oil, arvensis oil etc.), with the balance of production used domestically. India domestic consumption accounts for around 40 per cent of global consumption, China (20 per cent), Europe (15 per cent,) with Germany and Netherlands the major users and the USA (15 per cent) accounting for the bulk of consumption (ITC, Trade impact, 2014). The reason for improvement in Mentha cultivation is increasing internal consumption and its export potential to other countries (Chand et al. 2003). The objective of paper is to assess the export potential of Mentha oil from India and to study the direction of export and structural change in Mentha oil exports.

\section{REVIEW OF LITERATURE}

Krishnamoorthy and Raja (2020). The trend of pepper export is touching downwards from the year 2015 to 2020. In the year 2020 the trend has changed and the value of export increased to 32 per cent followed by a positive forecast to increase by 147 per cent. The trend of celery export is touching up from the year 2015 to 2021 and the value of export increased by a positive forecast to increase by 209.05 per cent. The trend of garlic export is moving up from the year 2015 to 2020. In the year 2020 the trend has changed value of export quantity declined to 13 per cent followed by a negative forecast to decline by 134.22 per cent.

Kanungo (2016) Country-wise export of turmeric shown that previous export share retaining for Indian turmeric higher in minor importing countries (pooled under others category) 87 per cent, followed by UAE 49 per cent, Iran 41 per cent and UK 35 per cent. The countries such as USA and Japan have not been the stable importers of turmeric from India.

Nair and Ramanathan (2014). Total export for the year 2010-11 comes to 31944 tons, almost 32,000 tons. The forecast for the years 2012, 2013 and 2014 was 40209 tons, 50934 tons and 64469 tons respectively.
The export performance has been stable over the last decade except in the year 2003-04 and year 2004-05 when the export figures shown a downward trend 11,250 tons and 11,830 tons respectively, when compared to the 13,589 tons, as well as in the year 2008-09 where the consistent growth did not reach the expected levels.

\section{MATERIALS AND METHODS}

Growth rate analysis and Markov chain analysis were the analytical tools used to assess growth and transition probabilities for the major Mentha oil markets. Time series data were collected from various published sources from the year 2010-11 to 2019-2020 to calculate the compound growth rate and export potential of Mentha oil.

\section{Analytical tools}

\section{(i) Growth Rate Analysis:}

$$
Y_{t}=a * b^{t}
$$

Where, $Y_{t}=$ dependent variable for which growth rate is estimated,

$a=$ intercept, $b=$ regression coefficient, $t=$ time variable

The growth rate coefficient (b's) was computed by transforming the equation in log form,

$$
\log T_{t}=\log a+t \log b
$$

Thus, Compound Annual Growth Rate in \% was computed as,

$$
C A G R=[(\text { antilog of } b-1) * 100]
$$

\section{(ii) Markov Analysis for export Potential}

$$
E_{j t}=\sum_{r=1}^{n} E_{(j t-1)} P_{i j}+e_{j t}
$$

Where,

$E_{j t}=$ export shift from I during the year $t$ to $j, E i_{t-1}=$ export of $i^{\text {th }}$ state during the year $t-1$,

$P_{i j}=$ The probability that export will shift from $i^{\text {th }}$ state to $j^{\text {th }}$ state, $e_{j t}=$ The error-term which is statistically independent of $E i_{t-1}$ and $r=$ the number of state. 
The transitional probabilities $P_{i j}$, which can be arranged in a $(c \times r)$ matrix, have the following properties:

$$
\begin{aligned}
& 0<=P_{i j}<=1 \\
& \sum_{i=1}^{n} P_{i j}=1
\end{aligned}
$$

\section{RESULTS AND DISCUSSION}

Compound annual growth rate (values in Lakh) of Mentha oil exported to different countries during the time period 2010-11 to 2019-20 was calculated. Table 1 depicted the value of the mentha oil exported to the various countries year wise.

Table 1 depicted the results that overall total compound annual growth rate (in values) of Mentha oil exported to different countries was 4.99 per cent over the years. The growth rate of U.K. was highest 11.66 per cent while on the other hand the growth rate of Brazil was lowest -15.62 per cent. The results further shown the overall coefficient of determination $\left(\mathrm{R}^{2}\right)$ of the importing countries was 0.225 . The UK was having highest coefficient of determination $\left(R^{2}\right) 0.55$. On the other hand, Germany was with the lowest coefficient of determination $\left(R^{2}\right) 0.002$. The reason behind the positive growth is increasing market demand of mentha oil by its consuming various industries. The direction of Indian Mentha oil exported towards different countries, the transitional matrix is depicted in the table 2 .

Table 2 revealed that country USA is the most stable importer of Indian Mentha oil because it retain 79 percent share in last ten years among all the countries. France reported as second most stable importer of India's mentha oil had 0.49 transition probability. Japan, Brazil, Netherland, Spain reported zero transition probability, indicating instability in India's exports to these countries. Germany had lowest retention probability of 0.04 is likely to gain from Spain (85 per cent), France (51 per cent) followed by Japan (45 per cent) and other countries (14 per cent). Netherland having zero probability of retention of its own share is likely to gain 21 per cent from Japan, 12 per cent from Germany and one per cent from U.K., China had 0.14 retention probability.

\begin{tabular}{|c|c|c|c|c|c|c|c|c|c|c|c|c|c|}
\hline $\begin{array}{l}\text { Sl. } \\
\text { No. }\end{array}$ & $\begin{array}{l}\text { Country/ } \\
\text { Year }\end{array}$ & 2010-11 & 2011-12 & 2012-13 & 2013-14 & 2014-15 & 2015-16 & 2016-17 & 2017-18 & 2018-19 & $2019-20$ & CAGR & $\mathbf{R}^{2}$ \\
\hline 1 & USA & 7354.22 & 11399.89 & 14565.44 & 23738.69 & 24925.94 & 17806.76 & 16270.83 & 20297.64 & 20349.19 & 23859.53 & $9.41^{*}$ & 0.503 \\
\hline 2 & China & 2356.59 & 3540.74 & 12125.02 & 8285.51 & 2856.81 & 1849.78 & 1870.84 & 2823.01 & 1671.42 & 5159.83 & -6.10 & 0.081 \\
\hline 3 & Japan & 511.53 & 1422.30 & 997.75 & 620.70 & 2514.46 & 2937.07 & 1246.38 & 2446.52 & 804.66 & 1543.85 & 7.99 & 0.149 \\
\hline 4 & Germany & 2436.43 & 4452.74 & 6401.61 & 5268.98 & 3781.14 & 3294.80 & 2807.04 & 3997.78 & 5209.90 & 3802.17 & 0.43 & 0.002 \\
\hline 5 & UK & 1129.47 & 2331.96 & 3424.86 & 4719.09 & 4394.55 & 3559.44 & 4475.04 & 4377.21 & 4091.76 & 5176.87 & $11.66^{* *}$ & 0.553 \\
\hline 6 & France & 2478.07 & 3489.25 & 4912.12 & 4615.75 & 4336.16 & 3056.77 & 2066.21 & 4088.74 & 3436.55 & 2534.51 & -2.15 & 0.050 \\
\hline 7 & Netherland & 243.40 & 847.68 & 1078.71 & 1247.30 & 620.18 & 804.75 & 960.50 & 942.46 & 589.21 & 989.96 & -5.53 & 0.122 \\
\hline 8 & Brazil & 242.24 & 758.68 & 994.83 & 209.48 & 155.91 & 50.65 & 37.96 & 187.12 & 63.03 & 377.37 & -15.62 & 0.220 \\
\hline 9 & Spain & 546.32 & 1070.13 & 1222.63 & 1254.68 & 631.44 & 439.35 & 343.81 & 873.54 & 741.77 & 1115.75 & -1.24 & 0.007 \\
\hline 10 & Singapore & 375.63 & 2751.89 & 1332.96 & 281.48 & 210.74 & 138.53 & 230.27 & 992.30 & 932.50 & 269.70 & -7.60 & 0.060 \\
\hline 11 & $\begin{array}{l}\text { Total of } \\
\text { others }\end{array}$ & 1578.28 & 3899.42 & 4948.99 & 3175.43 & 3031.47 & 2438.10 & 2460.37 & 4339.68 & 7159.72 & 6810.67 & 10.03 & 0.368 \\
\hline 12 & Total & 19252.18 & 35964.68 & 52004.92 & 53417.09 & 47458.80 & 36376.00 & 32769.25 & 45366.00 & 45049.71 & 51640.21 & 4.99 & 0.225 \\
\hline
\end{tabular}

Table 1: Compound Annual Growth Rate of Mentha oil exported toward different countries (Value in ₹ (Lakh))

Source: Ministry of Commerce and authors own computation.

*Significant at $5 \%$ level of probability; **Significant at 1\% level of probability. 
Table 2: Direction of Indian Mentha oil exported towards different countries (Transitional Matrix)

\begin{tabular}{lllllllllll}
\hline Country & U.S.A & China & Japan & Germany & UK & France & Netherland & Brazil & Spain & Others \\
\hline USA & $\mathbf{0 . 7 9}$ & 0.00 & 0.08 & 0.00 & 0.11 & 0.03 & 0.00 & 0.00 & 0.00 & 0.00 \\
China & 0.71 & $\mathbf{0 . 1 4}$ & 0.00 & 0.00 & 0.15 & 0.01 & 0.00 & 0.00 & 0.00 & 0.00 \\
Japan & 0.11 & 0.00 & $\mathbf{0 . 0 0}$ & 0.45 & 0.23 & 0.00 & 0.21 & 0.00 & 0.00 & 0.00 \\
Germany & 0.37 & 0.27 & 0.00 & $\mathbf{0 . 0 4}$ & 0.00 & 0.00 & 0.12 & 0.01 & 0.19 & 0.00 \\
UK & 0.17 & 0.00 & 0.00 & 0.00 & $\mathbf{0 . 2 1}$ & 0.11 & 0.01 & 0.00 & 0.00 & 0.49 \\
France & 0.00 & 0.00 & 0.00 & 0.51 & 0.00 & $\mathbf{0 . 4 9}$ & 0.00 & 0.00 & 0.00 & 0.00 \\
Netherland & 0.00 & 0.00 & 0.00 & 0.00 & 0.00 & 1.00 & $\mathbf{0 . 0 0}$ & 0.00 & 0.00 & 0.00 \\
Brazil & 0.00 & 0.98 & 0.00 & 0.00 & 0.00 & 0.00 & 0.00 & $\mathbf{0 . 0 0}$ & 0.02 & 0.00 \\
Spain & 0.00 & 0.00 & 0.00 & 0.85 & 0.00 & 0.15 & 0.00 & 0.00 & $\mathbf{0 . 0 0}$ & 0.00 \\
Others & 0.00 & 0.35 & 0.00 & 0.14 & 0.00 & 0.00 & 0.00 & 0.03 & 0.00 & $\mathbf{0 . 4 8}$ \\
\hline Source:
\end{tabular}

Source: Authors computation from secondary data.

\section{CONCLUSION}

Indian mentha oil has competitive advantages among the countries. USA is the stable consumer of Indian mentha oil so trade policy regarding mentha oil should be in mutual coordination with country USA. India should have to continue trade of Mentha oil with France because it seems like France will be the stable importer of Mentha oil in future. Better price recovery of Mentha oil may attract to small farmers for cultivation of Mentha crop. The factors which influences Mentha oil market is international factors like import demand from major Mentha oil importing countries such a country USA etc.. Production, consumption and stock of Mentha oil are also influences the compound annual growth rate of Mentha oil.

\section{REFERENCES}

Chand, S., Patra, N.K., Anwar, M. and Patra, D. 2004. Agronomy and Use of Menthol Mint- Indian perspectives. Proc. Indian Natl. Sci. Acad., B70: 269-297.

ICAR- CCARI, agri e- portal. RKVY. Retrieved July 10, 2021, 16:52 pm, from https://www.agrigoaexpert.res.in/icar/ category/horitculture/medicinal_aromatic_crops/Mint.

ITC, Trade Impact 2014 An Overview of Mentha arvensis Production. Retrieved July 06, 2021, 03:15 pm from https://www.intracen.org/uploadedfiles/intracenorg/ content/exporters/market_Data_and_Information/ Market_information/Market.
Kanungo, S. 2016. Trend Analysis of Turmeric Exported from India and Associated Foreign Earnings. Int. J. Res. Econ. Soc. Sci., 6(11): 99-105.

Krishnamoorthy, D. and Raja, V. 2020. A study on trend analysis of spices export from India. J. Contemporary Issues in Business and Gov., 26(2): 865-873.

Nair, P. and Ramanathan, H. 2014. The Future of Indian Mint A Study to Forecast the Mint Exports from India. Int J Supply Chain Management Systems, pp.1-12. Retrieved July 07, 2021, 03:36 pm, from http://www.publishingindia.com

Srivastava, R. 2013. The mint that grows profits for farmers. Hindustan Times. Retrieved July 10, 2021, 5:10 pm fromhttps://www.hindustantimes.com lucknow/the-mintthat-grows-profits-for-farmers/story.

Singh, S.P., Raj, T., Singh, A., Verma, D.K. and Kumar, S. 2019. Relative economics of menthol mint cultivation with existing competitive crop combinations in Dudhwa tiger reserve area of Uttar Pradesh. Econ. Affa., 64(4): 725-731.

Chandrasekhar, G. 2017. Mentha oil growing demand. The Hindu. Retrieved July 10, 2021, 5:10 pm from https:// www.thehindubusinessline.com/opinion/columns/ g-chandrashekhar/Mentha-oil-Growing-demand/ article20393527

Time IS FICCI. Retrieved July 10, 2021, 6:48 pm, from $h t t p: / /$ www.techno-preneur.net/technology/project-profiles/chemical/ menthol.html. 